\title{
A RARE CASE OF MYXEDEMA IN PREGNANCY
}

Narmadha ${ }^{1}$, Jamila Hameed ${ }^{2}$, Radhika ${ }^{3}$, Varsha ${ }^{4}$

\section{HOW TO CITE THIS ARTICLE:}

Narmadha, Jamila Hameed, Radhika, Varsha. "A Rare Case of Myxedema in Pregnancy". Journal of Evolution of Medical and Dental Sciences 2014; Vol. 3, Issue 17, April 28; Page: 4513-4515,

DOI: $10.14260 /$ jemds/2014/2467

ABSTRACT: The incidence of hypothyroidism in pregnancy is $2-3 \%$, subclinical hypothyroidism is 2$2.5 \%$ and overt hypothyroidism is $0.3-0.5 \%$. Hypothyroidism may cause abortion, placental abruptions, pre-eclampsia, intrauterine growth restriction (IUGR), preterm delivery and mental retardation of the baby .Treating clinical and subclinical hypothyroidism may reduce adverse obstetric outcomes. Universal screening is currently not recommended. Thyroid dysfunction and thyroid autoimmunity are prevalent among women of reproductive age. Preconception or early pregnancy screening for thyroid dysfunction has been proposed but is not widely accepted. A 21year old primi with nine months of amenorrhoea with oligohydramnios with hypothyroidism was referred from outside for safe confinement. She had hoarseness of voice, nonpitting edema, puffiness of face and had high blood pressure (preeclampsia). Cesarean section was done and an alive male $2 \mathrm{~kg}$ baby was delivered and had feature of IUGR . Patient had atonic postpartum haemorrhage (PPH). She was resuscitated with blood and prostodin. She was advised to continue thyroid drugs . Preconception or early pregnancy screening for thyroid dysfunction is essential just like diabetics screening hence there is a need for increased awareness. The early diagnosis and treatment will solve the problems of hypothyroidism in pregnancy.

KEYWORDS: Hypothyroidism, preeclampsia, pregnancy

CASE REPORT: A 21yrs old primi with 9months amenorrhea with oligohydramnios with hypothyroidism was referred from outside for safe confinement. Patient perceived fetal movements well. She had hoarseness of voice, swelling of both legs and face for the past 2 months, breathlessness for the past 1 week. She had diffused enlarged thyroid gland. She also had high blood pressure 150/90mm Hg. She had preeclampsia. No significant past history. LMP: 27/10/2012 EDD: 03/08/2013 GA: 35w 4 d. She had routine investigations Proteinuria was present. Decreased serum thyroxine $\left(\mathrm{T}_{4}\right)$, decreased serum triiodothyronine $\left(\mathrm{T}_{3}\right.$ ) and elevated serum thyroid stimulating hormone (TSH) were noted. Ultrasound and doppler study showed: Single intrauterine gestation corresponding to 34-35 weeks with grade 3 anterior placenta.

Umbilical artery showing high resistance flow signs of fetoplacental compromise. So she was diagnosed as myxedema pregnancy with preeclampsia with IUGR .Patient was given levothyroxine $150 \mu \mathrm{g}$ the dosage was doubled since she was pregnant. She had fetal heart rate monitoring done which showed fetal distress and emergency LSCS was done because of impending eclampsia.

Injection betamethasone was given and a baby boy weighing $2 \mathrm{~kg}$ was born (IUGR). In the immediate post-partum period, patient had PPH which was managed with syntocinon 20U drip, injection prostodin and misoprostol. Blood transfusion was given. Baby was feeding well and had a normal thyroid function test. Patient was discharged with levothyroxin therapy and hematinic. She was asked to come for review with reports of TSH. 


\section{CASE REPORT}

DISCUSSION: Hypothyroidism may be noted for the first time in pregnancy because:

1. A patient who had been prescribed thyroid drugs for infertility might have stopped.

2. Failure to increase the thyroid drug dosage which had been prescribed preconceptionally.

3. The patient had been taking lithium, amiodarone

4. Hyperthyroid cases taking excessive antithyroid therapy.

5. Primary hypothyroidism is due to thyroid autoimmunity in pregnancy.

Myxedema generally leads to infertility. Serum thyroid peroxidase antibodies, antimicrosomal antibodies are elevated in autoimmune thyroiditis. Myxedema in pregnancy is a rare occurrence ${ }^{1}$ The severest form of hypothyroidism is myxedema where there is accumulation of mucopolysaccharides in the skin and other tissues, causing thickening of the facial features, hyperpigmentation, edema of the neck, shoulder, back, face and abdomen. Skin problems leading to infection and inflammation are common in myxedematous skin changes. Hypothyroidism causes complications both in the mother and the baby (table 1 ).

Levothyroxine treatment in clinical and subclinical hypothyroidism is a standard practice in order to reduce the adverse effect in the outcome of pregnancy. Intervention for clinical and subclinical hypothyroidism in pregnancy is essential ${ }^{2}$ Preeclampsia $^{3}$ may go in for eclampsia and coma. ${ }^{4}$ In early pregnancy, the hCG causes increased TSH and hypothyroidism. The increased excretion of urinary iodide also contributes. The immunological state of pregnancy is also a factor.

The thyroid binding globulin which increases during pregnancy causes hypothyroidism as such even subclinical hypothyroidism can go in for overt hypothyroidism.

In subclinical hypothyroidism T3, T4 are normal only TSH is increased without the signs of hypothyroidism like tiredness, dry skin, feeling cold, hair loss, difficulty in concentration and weight gain in spite of poor appetite. In a case of overt hypothyroidism T4, T3 are decreased, TSH is increased above $10 \mathrm{mU} / \mathrm{L}$ with obvious signs.

TSH level is the main indicator for the dosage schedule which has to be done every six weeks. Preconception or early pregnancy screening for thyroid dysfunction is essential and will be useful in preventing the complications. Screening for thyroid disorders is mandatory though controversial. ${ }^{5}$

CONCLUSION: There is no universal screening programme for hypothyroidism like diabetes screening; hence cases of hypothyroidism go in for severe complications during pregnancy. Moreover subclinical cases become overt hypothyroidism during pregnancy. Routine screening of thyroid state during pregnancy is mandatory since pregnancy influences the thyroid function.

\section{REFERENCES:}

1. Blignault EJ. Advanced pregnancy in a severely myxoedematous patient: A case report and review of the literature. S Afr Med J. 1980 Jun 21; 57 (25):1050-1.

2. Reid SM, Middleton $\mathrm{P}$, Cossich MC, Crowther CA. Interventions for clinical and subclinical hypothyroidism in pregnancy. Cochrane Database Syst Rev.2010Jul 7; (7)

3. Alfadda A, Tamilia M. Preeclampsia-like syndrome that is associated with severe hypothyroidism in a 20-week pregnant woman. Am J Obstet Gynecol. 2004 Nov; 191(5):1723-4.

4. Turhan NO, Koçkar MC, Inegöl I. Myxedematous coma in a laboring woman suggested a preeclamptic coma: a case report. Acta Obstet Gynecol Scand. 2004 Nov; 83(11): 1089-91.

5. Horacek $\mathrm{J}$ et al. Universal screening detects two-times more thyroid disorders in early pregnancy than targeted high-risk case finding. Eur J Endocrinol. 2010 Oct;163(4):645-50 


\section{COMPLICATIONS:}

\begin{tabular}{|c|c|}
\hline Mother & Baby \\
\hline $\begin{array}{l}\text { - } \text { Thickened skin changes } \\
\text { - } \text { Carpel tunnel syndrome } \\
\text { - Pericardial effusion } \\
\text { - } \text { Pseudomyotonia } \\
\text { - } \text { Slow tendon reflex } \\
\text { - } \text { Abortion } \\
\text { - Preeclampsia } \\
\text { - } \text { gestational hypertension } \\
\text { - Placental abruption } \\
\text { - Preterm delivery, very preterm delivery } \\
\text { - } \text { (<32 weeks) } \\
\text { - Postpartum hemorrhage }\end{array}$ & $\begin{array}{l}\text { - Preterm birth } \\
\text { - } \text { Low birth weight } \\
\text { - } \text { Perinatal morbidity and mortality } \\
\text { - } \text { Increased NICU admission } \\
\text { Neuropsychological and cognitive } \\
\text { impairment: } \\
\text { - Congenital cretinism - growth } \\
\text { restriction, deafness, } \\
\text { neuropsychiatric impairment } \\
\text { from severe Iodine deficiency or } \\
\text { untreated congenital } \\
\text { hypothyroidism }\end{array}$ \\
\hline
\end{tabular}

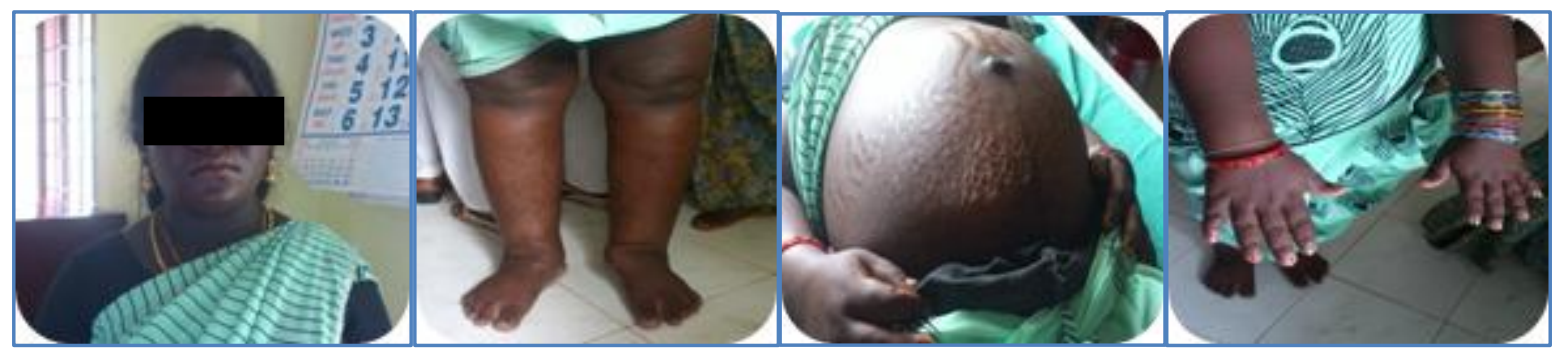

Figure: (puffy eyelids, thickened skin, myxedematous legs, hyerpigmented skin)

\section{AUTHORS:}

1. Narmadha

2. Jamila Hameed

3. Radhika

4. Varsha

\section{PARTICULARS OF CONTRIBUTORS:}

1. Tutor, Department of Obstetrics and Gynaecology, Vinayaka Mission's Medical College \& Hospitals, Karaikal.

2. Professor, Department of Obstetrics and Gynaecology, Vinayaka Mission's Medical College \& Hospitals, Karaikal.

3. Professor, Department of Obstetrics and Gynaecology, Vinayaka Mission's Medical College \& Hospitals, Karaikal.
4. Post Graduate, Department of Obstetrics and Gynaecology, Vinayaka Mission's Medical College \& Hospitals, Karaikal.

\section{NAME ADDRESS EMAIL ID OF THE CORRESPONDING AUTHOR:}

Dr. Jamila Hameed,

Department of Obstetrics and Gynaecology,

Vinayaka Mission's Medical College \& Hospitals, Karaikal.

E-mail: jamilahameed@gmail.com

Date of Submission: 25/03/2014.

Date of Peer Review: 26/03/2014.

Date of Acceptance: 08/04/2014.

Date of Publishing: 23/04/2014. 